\title{
Evaluation of proposed integrated diseases management strategies in blackberry cultivation according to its sustainability
}

\begin{abstract}
Yimmy Alexander Zapata Narváez ${ }^{1}$ \& Camilo Rubén Beltrán-Acosta²
Abstract-The production of blackberry in Colombia is a source of income and rural employment in 18 departments; however, the plant is affected by diseases such as gray mold, anthracnose and powdery mildew that can cause losses of up to $70 \%$. The control of these diseases is mainly carried out with chemical fungicides such as benomyl, carbendazim and mancozeb applied every 7 or 15 days. Nevertheless, being a continuous fructification plant of weekly harvest, the proximity between the application of the pesticides, the harvest, and its consumption represents a health risk due to the residually of these molecules, condition that affects its innocuousness and sustainability. Accordingly, this work aimed to develop an integrated management strategy for these diseases. Two strategies were proposed integrating agricultural labors with applications of Tricotec ${ }^{\circledR}-$ Kendal $^{\circledR}$ or Tricotec ${ }^{\circledR}-$ EcoSwing $^{\circledR}$, and three fungicides applied according to the incidence of each disease, compared with the diseases producer management. In 77 evaluation days the effectiveness of the strategies was assessed according diseases incidence reduction, on fruit production, environmental impact, using the environmental impact quotient in the field (EIQf), and the reduction of fruit pesticides residues. According to the results obtained, the strategy Tricotec ${ }^{\circledR}-K_{e n d a l}{ }^{\circledR}$ with applications of a fungicide based on azoxystrobin + difeconazole showed the lowest diseases incidence, averaging 3\% for gray mold, $11 \%$ for anthracnose, and $21 \%$ for powdery mildew and the highest amount of fruit harvested averaging 5,668 g. The strategy showed the lowest EIQf (5.3) compared with a value of 81.50 obtained with the traditional producer management, as well as the least amount of pesticides residues, corresponding to azoxystrobin $(0.10 \mathrm{mg} / \mathrm{kg})$ and difeconazole $(0.046 \mathrm{mg} / \mathrm{kg})$; these, however, remained within the maximum residue limits for pesticides stated by the European Union for blackberry.
\end{abstract}

Index terms: Control, efficacy, food safety, environmental impact, residuality.

\section{Avaliação das estratégias propostas para a gestão integrada de doenças da cultura de amora, em função de sua sustentabilidade}

\section{Corresponding author: jzapatan@agrosavia.co}

Received: March 05, 2019 Accepted: June 03, 2019

Copyright: All the contents of this journal, except where otherwise noted, is licensed under a Creative Commons Attribution License.

\section{$(\mathrm{cc}) \mathbf{E Y}$}

Resumo - A produção de amora na Colômbia é uma fonte de renda e emprego rural em 18 estados; no entanto, a planta é afetada por doenças como mofo-cinzento, antracnose e oídio, que podem causar perdas superiores a 70\%. Seu controle é realizado principalmente com fungicidas químicos, como benomil, carbendazim ou mancozeb, aplicados a cada 7 ou 15 dias. No entanto, por ser uma planta de frutificação contínua e colheita semanal, a proximidade temporal entre a aplicação de pesticidas, a colheita e seu consumo representa um risco à saúde devido à residualidade dessas moléculas, condição que afeta sua segurança e sustentabilidade. Nesse sentido, este trabalho teve como objetivo desenvolver uma estratégia de gestão integrada para essas doenças. Para isso, duas estratégias foram propostas,

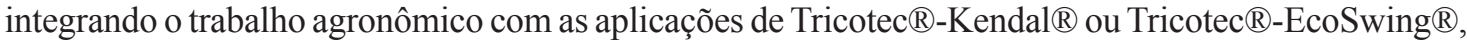
e três fungicidas aplicados de acordo com a incidência de cada doença, comparando-os com o manejo convencional do produtor. Durante o período de 77 dias, sua eficácia foi determinada na redução da incidência, produção de frutas, seu impacto ambiental, calculando o coeficiente de impacto ambiental no campo (CIAc) e na redução de resíduos de pesticidas nas frutas. De acordo com os resultados obtidos, foi estabelecido que a estratégia Tricotec ${ }^{\circledR}-K e n d a l \circledast$, com aplicações de fungicida à base de azoxistrobina e difeconazol, apresentou a menor incidência para cada doença, com média de 3\% para mofo-cinzento, $11 \%$ para antracnose e $21 \%$ para oídio, e a maior quantidade de frutas colhidas, em média 5.668 g. Além disso, apresentou o menor CIAc, com 5,3, comparado a um valor de 81,50 do manejo convencional do produtor, bem como a menor quantidade de vestígios de pesticidas, correspondendo a azoxistrobina $(0,10 \mathrm{mg} / \mathrm{kg})$ e difeconazol $(0,046 \mathrm{mg} / \mathrm{kg})$; no entanto, estes estavam dentro dos limites máximos de resíduos de pesticidas autorizados pela União Europeia por amoras.

Termos para indexação: Controle, eficiência, segurança, impacto ambiental, residualidade.

\footnotetext{
${ }^{1}$ Corporación Colombiana de Investigación Agropecuaria - Agrosavia. Centro de Investigación Tibaitata - Cundinamarca-Colombia. E-mail: jzapatan@agrosavia.co(ORCID 0000-0002-7586-209X)

${ }^{2}$ Corporación Colombiana de Investigación Agropecuaria - Agrosavia. Centro de Investigación Tibaitata - Cundinamarca-Colombia. E-mail: cbeltran@agrosavia.co (ORCID 0000-0002-6063-6962)
} 


\section{Introduction}

In Colombia blackberry is an important crop because it is cultivated by small producers in areas ranging from 0.5 to $5 \mathrm{ha}$, comprising a total cultivated area of 15,062 ha; in 2017 and a yield of $7.88 \mathrm{t} / \mathrm{ha}$, obtained in the ten main producing state in the country (SIEMBRA, 2018). These are mostly located in the Andean region between 1,800 and 2,800 meters above the sea level, with average day temperature between 12 and $18{ }^{\circ} \mathrm{C}$ and an average accumulated rainfall between 1,500 and 2,500 mm per year (SORA et al., 2006).

Despite the adequate environmental conditions for blackberry cultivation, it is largely affected by diseases that limit its production; the most important are the gray mold caused by the fungus Botrytis cinerea Pers.:Fr., anthracnose by the fungus Colletotrichum gloeosporioides (Penz.) Penz. and Sacc., and the powdery mildew by the fungus Sphaerotheca macularis (Wallr), which can cause losses from $50 \%$ to $100 \%$ (TAMAYO, 2001; MARULANDA et al., 2007; BOYZO et al., 2015).

$B$. cinerea affects any fruit development stage infecting different floral structures and remains in a quiescent state if the conditions do not favor its development (JARVIS, 1962; MOLINA et al., 2004). However, once the fruit is mature, this fungus reproduces aggressively producing abundant conidia, which infects other flowers or fruits, causing its loss both in the field and during postharvest. C. gloeosporioides affects mainly the stems, branches, and fruits, producing in the first, necrosis inside the tissues that causes plant death (ARENAS et al., 2007; WEIR et al., 2012). On the other hand, S. macularis produces a disease that occurs in slightly drier conditions, affecting mainly the leaves whose characteristic sign is the powdery growth of a whitish color, which corresponds to spores production. This leads to a reduction in photosynthesis as the mycelium covers the leaves and produces necrosis and subsequent defoliation, affecting fruit production yield (AMSALEM et al., 2006; CARISSE et al., 2013).

The main control methods for these fungi is the application of chemical fungicides, particularly employing products with molecules such as captan, benomyl, carbendazim, chlorothalonil, copper oxychloride, cupric hydroxide, mancozeb, and metalaxyl, among others, which are usually applied with a frequency of seven or 15 days, without rotation schemes (NARANJO-MARÍN, 2011).

As blackberry is a continuous fructification plant whose fruit is harvested weekly, pesticide residuals tend to be a common aspect of their production, mainly because scarcity periods cannot be met (between seven and 21 days). Therefore, given the temporal proximity between applications, the harvest, and its consumption represents a significant risk to human health given the residuality of the pesticides in the products.

Additionally, the prolonged use, overdosage and inadequate use of pesticides also represent a contamination risk for the agroecosystem, mainly because some of the pesticides used have a half-life of up to five weeks (UNIVERSITY OF HERTFORDSHIRE, 2017a). Its persistence in the soil can have adverse effects in the micro and macrobiota affecting processes such as the degradation of organic matter, which facilitates nutrient cycling (WIGHTWICK et al., 2010).

Likewise, many blackberry plots are located close to water sources which can become contaminated affecting the biodiversity in these ecosystems (UNIVERSITY OF HERTFORDSHIRE, 2017a). Regarding the effect on arthropods, mainly pollinators, these can be exposed to fungicides as a result of their food-seeking activities, and although some may not have a toxic effect on their health, can cause repellency towards the substrate (flowers), disorientation or behavioral changes, reducing their presence and consequently a reduction in flower pollination (VANENGELSDORP et al., 2010; BRITTAIN et al., 2010).

In this context, the current condition in which blackberry is cultivated affects its sustainability and impacts fruit safety. Therefore, it is a priority to develop and implement diseases management strategies that consider the use of different alternatives, whether biological, chemical or cultural, that integrated, lead to a technical change that positively impacts the sustainability of the agroecosystem. Accordingly, this work aimed to develop an integrated management strategy for the most important diseases in blackberry crop including the application of bioproducts and fungicides according to the incidence of the diseases, and the implementation of agronomic labors.

\section{Materials and Methods}

\section{Study area and planting scheme}

The study was carried out in the town of El Carmelo in the municipality of El Colegio, state of Cundinamarca, Colombia, located at $1,983 \mathrm{~m}$ above the sea level with an average temperature of $18^{\circ} \mathrm{C}$, and an annual accumulated rainfall of 2,000 mm per year (IDEAM, 2015). In this area, a plot of 260 blackberry plants was established with planting distances of $2.5 \times 2.5 \mathrm{~m}$ using a crop support system that allows plant aeration and opening.

Assessment of integrated diseases management strategies for blackberry cultivation

Two integrated diseases management strategies that included the use of bioproducts, the application 
of fungicides according to the diseases incidence, and agronomic labors were proposed and assessed to reduce the incidence of the principal blackberry diseases, to increase fruit production, reduce the environment impact and pesticide residues in the harvested fruit.

The following bioproducts were selected, considering their efficacy in the control of gray mold, anthracnose, and powdery mildew. The first is the biofungicide Tricotec ${ }^{\circledR}$ elaborated with the fungus Trichoderma koningiopsis strain Th003 developed by Agrosavia; the second is the plant biostimulant Kendal ${ }^{\mathbb{B}}$ (Valagro, https://www.valagro.com/es/farm/productos/) that contains oligosaccharins and glutathione; and the third is the plant extract based on Swinglea glutinosa EcoSwing $^{\circledR}$ (Ecoflora Agro, http://www.ecofloragro.com/ ecoswing/). Moreover, according to the diseases incidence, three fungicides registered for blackberry crop by Instituto Colombiano Agropecuario (ICA, 2017) were used.

The treatments considered were as follows: i) A mixture of Tricotec $^{\circledR}$ and Kendal ${ }^{\circledR}{ }^{(T r i c o t e c} 1$ g. $L^{-1}$, Kenda $^{\circledR} 1.5$ mL.L $\left.{ }^{-1}\right)$; ii) A mixture of Tricotec ${ }^{\circledR}$ and EcoSwing $^{\circledR}$ (Tricotec 1 g.L $\mathrm{L}^{-1}$, EcoSwing ${ }^{\circledR} 1.5$ mL.L $\mathrm{L}^{-1}$ ); applied foliarly in a frequency of 15 days. According to the diseases incidence, the application of three fungicides was considered: a based on thiram + pyrimethanil for $B$. cinerea, another based on azoxystrobin + difeconazole for C. gloeosporioides, and a third one based on fluopicolide + propineb for $S$. macularis. These treatments were compared with the traditional producer management, consisting of applications of benomyl and mancozeb for gray mold, benomyl and carbendazim for anthracnose and a fungicide based on propineb + cymoxanil for powdery mildew, in a frequency of 15 days.

The agronomic labors consisted of a sanitary pruning previous to the beginning of the applications of the treatments (stems and nonproductive branches that increase foliage density, broken branches or with symptoms of any pathology were eliminated). For the treatments where the bioproducts applications were assessed, three maintenance prunings were carried out at intervals of one month in order to keep the plants unobstructed; conversely, the producer management treatment was only carried out once.

The variables evaluated were the incidence and severity of the diseases, quantified each week for 77 days. For gray mold, the percentage of incidence was determined, selecting each week of each treatment 16 plants, quantified the healthy fruits suitable for harvest and the fruits that showed disease signs. For anthracnose, at the start of the bioassay 16 plants were selected and the asymptomatic stems were marked. Then, the incidence was established as the number of stems with symptoms over all plant stems; meanwhile, disease severity was measured with a severity scale of six levels according to the affected area $(1: 0 \%$, healthy; $2: 1-20 \% ; 3: 21-40 \%$;
4: $41-60 \% ; 5: 61-80 \%$; and 6: $81-100 \%$ ). For powdery mildew, each week 16 plants were selected, and of these, three stems were chosen to establish the disease incidence as the number of leaflets with disease signs or symptoms over the total number of leaflets in the stem. The disease severity was measured using a severity scale with five levels according to the affected area (1: $0 \%$, healthy, 2 : 1-25\%, 3: $26-50 \%, 4: 51-75 \%$; and 5: 76-100\%). This measurement was only carried out in the apical leaflet due to the high number of leaflets per stem, modifying the scale proposed by REBOLLAR-ALVITER et al., 2012.

Likewise, fruit production per treatment was evaluated through a weekly quantification, and its statistical analysis was carried out based on total yield.

\section{Statistical analysis}

The bioassay was developed under a divided plots design with 48 plants, where each plant was a sampling unit. The plots were separated from each other by two rows of plants that were not treated in order to avoid contamination between treatments. The temperature and relative humidity $(\mathrm{RH})$ were recorded with a Data Logger (Omega $\left.{ }^{\mathrm{TM}} \mathrm{OM}-62\right)$ to establish their effect on the diseases incidence.

The results obtained were analyzed through a non-parametric Kruskal-Wallis test and Dunn's pairwise comparison test with $\alpha: 0.05$, using the statistical analytical software package Statistix 10.0.

\section{Environmental Impact Quotient in the field}

The environmental impact quotient in the field (EIQf) was calculated using the methodology proposed by Kovach et al. (1992). Initially, the environmental impact quotient (EIQ) was calculated for each pesticide or biopesticide used, employing the equation that relates the three main components included in agricultural production systems, i.e., the worker, the consumer and the fauna, using the following equation:

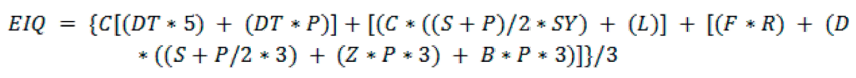

Where $\mathrm{C}=$ Chronic toxicity. $\mathrm{DT}=$ Dermal toxicity. $\mathrm{SY}=$ Systemicity. $\mathrm{S}=$ Half-life in the soil. $\mathrm{L}=$ Leaching potential. $\mathrm{R}=$ Runoff potential. $\mathrm{P}=$ Half-life in the plant surface. $\mathrm{D}=$ Toxicity in birds. $\mathrm{F}=$ Toxicity in fish. $\mathrm{B}=$ Toxicity in beneficial insects. $Z=$ Toxicity in bees.

Some EIQ values for several pesticides are published in the "New York State Integrated Pest Management of Cornell University. List of Pesticide Active Ingredient EIQ values" (CORNELL UNIVERSITY, 2017). For those that are not on this list, the values were calculated from the technical data sheets that pesticide manufacturers report 
for their products.

Once the EIQ was established for each pesticide or biopesticide in each strategy, the EIQf was determined using the following equation:

$$
E I Q f=E I Q * A I * \text { dose } * \text { frequency }
$$

Where EIQ= The environmental impact quotient of each pesticide. $\mathrm{AI}=$ The active ingredient of the formulated product. Dose $=$ The quantity of product applied in the field. Frequency $=$ The number of applications.

\section{Effect on the reduction of pesticide residues}

One week before the last data registry was carried out and without changing the application times of the products in each treatment (according to the day in which the fruit was harvested), one kilogram of fruit was collected per treatment to carry out as soon as possible, the pesticides residuality analysis in the Primoris Colombia Laboratory by liquid chromatography and mass spectrophotometry (LC-MS). With these results, the difference between the strategies proposed and the traditional producer management was established concerning the maximum residue limits (MRL) stated for blackberry according to the European Commission (EUROPEAN UNION, 2017).

\section{Results and Discussion}

\section{Assessment of integrated diseases management strategies for blackberry cultivation}

During the evaluation period, the environmental conditions favored the diseases incidence, averaging $84 \%$ of $\mathrm{RH}$ and a temperature of $17{ }^{\circ} \mathrm{C}$ (Figure 1). For some days, particularly in the third, sixth, ninth, tenth and eleventh weeks, the RH present an average of $75 \%$ with and temperature average of $23{ }^{\circ} \mathrm{C}$ (Figure 1), corresponding to the decrease in the gray mold and powdery mildew incidence. In contrast, the rest of the weeks presented an average of $93 \%$ to $\mathrm{RH}$ and a temperature between $10{ }^{\circ} \mathrm{C}$ and $15^{\circ} \mathrm{C}$ (Figure 1), showed an increment in the incidence and severity of the diseases.

The incidence of gray mold fluctuated during the evaluation period, being higher when the RH was equal to or higher than $90 \%$. Regarding its control, with the applications of Tricotec ${ }^{\circledR}-\mathrm{Kendal}^{\circledR}$ the lowest incidence was found with an accumulated average of $3 \%$ and a maximum of $5 \%$. Meanwhile, with the applications of Tricotec ${ }^{\circledR}-E \operatorname{coSwing}{ }^{\circledR}$, the average accumulated and maximum incidences were higher $(6 \%$ and $19 \%$, respectively). Furthermore, for the producer treatment, the cumulative average and maximum incidences showed the highest values (13\% and 26\%, respectively) (Figure 2).

In relation to anthracnose, the number of stems with disease symptoms increased between the beginning and the end of the evaluation period, although with the applications of Tricotec $^{\circledR}$-Kendal ${ }^{\circledR}$ the lowest incidence was obtained at the end the evaluation with $22 \%$, meanwhile with Tricotec $^{\circledR}$-EcoSwing ${ }^{\circledR}$ this value was $42 \%$ (Figure 3 ). In these treatments, two applications of the fungicide based on azoxystrobin + difeconazole were made to avoid an increase in incidence, particularly during the period where the environmental conditions were favorable for the development of the disease. In terms of severity, these treatments showed a constant level of 2 during the evaluation period. On the contrary, the producer treatment showed the highest incidence at the end of the bioassay with $76 \%$ (Figure 3), and with a severity level of 3 .

The powdery mildew incidence fluctuated according to the environmental conditions, however, with the applications of Tricotec ${ }^{\circledR}-K_{\text {Kendal }}{ }^{\circledR}$ the lowest incidence of the disease was obtained with an accumulated average of $21 \%$, meanwhile, with Tricotec ${ }^{\circledR}$-EcoSwing ${ }^{\circledR}$, the incidence was $43 \%$. Therefore, three applications of fluopicolide + propineb were necessary for this treatment when the incidence exceeded $30 \%$ (Figure 4). Concerning its severity, the affected leaflets presented a constant level of 2, however, with the increase of the $\mathrm{RH}$, a progression of the damage was observed up to a level of 3 , particularly in week four of the evaluation period. This is the reason why an application of the fungicide had to be carried out. For the producer treatment, the highest incidence occurred at the end of the bioassay with $71 \%$ (Figure 4) with a severity level of 4 .

Fruit production showed a progressive development through time, i.e., the beginning of the evaluation period corresponded with the start of the plant production stage, given that at this point, plants were one year old; further, this is the estimated time for the start of blackberry fruit production. In this sense, the most significant amount of fruit harvested per week was found in the Tricotec ${ }^{\circledR}$ Kendal ${ }^{\circledR}$ treatment with an average of 5,668 g; meanwhile, for the Tricotec $^{\circledR}-$ EcoSwing $^{\circledR}$ treatment, this value was lower with 4,017 $\mathrm{g}$ and even lower with the producer treatment with an average of 3,100 $\mathrm{g}$ (Figure 5).

According to the efficiency of the strategies proposed to diseases control as well as concerning fruit production, the strategy that integrated the applications of Tricotec ${ }^{\circledR}$-Kenda $l^{\circledR}$ and the two applications of the fungicide based on azoxystrobin + difeconazole were highlighted.

Kenda ${ }^{\circledR}{ }^{\circledR}$ is a foliar biostimulant that contains plant extracts, whose main composition are oligosaccharins and glutathione, molecules that act as elicitors and are associated with the stimulation of defense response in the plant (MERT-TÜRK, 2002; GARCIA-BRUGGER et 
al., 2006; GUEVARA et al., 2010). Given the properties of these molecules, it is possible that this phenomenon occurred to the blackberry plants assessed in this study, and that this occurrence had an effect on $S$. macularis and $C$. gloeosporioides, pathogens whose life modes (biotrophy and hemibiotrophy) limit the action of antagonistic fungi such as Trichoderma spp. This occurs because, at a certain point in their life cycle, these pathogens are found within the plant tissue, limiting the action of control mechanisms such as mycoparasitism or space and nutrients competition (CARISSE et al., 2013; WEIR et al. al., 2012).

In a study carried out by Boyzo et al. (2015) using applications of Kendal ${ }^{\mathbb{B}}$ and two biopesticides, one based on Bacillus subtilis and another based on Trichoderma harzianum, a seed extract of citrus fruits and a fungicide based on copper sulfate during a three-year evaluation period, efficient results in the control of Peronospora sparsa (another biotrophic pathogen that produces black hairless mildew in blackberry) was obtained. This study showed a lower incidence of the disease using the Kendal ${ }^{\mathbb{R}}$ treatment $(13 \%)$ compared to the other treatments assessed (between $15 \%$ and 19\%).

On the other hand, pathogens like $B$. cinerea are susceptible to the absence of nutrients, limiting the germination of the conidia and the subsequent infection processes (ELAD, 1996). Thus, through the application of antagonists such as Trichoderma spp. that shows modes of action such as space and nutrients competition, mycoparasitism or antibiosis, there might have been an inhibition in the development of the propagules of the pathogen, reducing the infection processes in different floral structures as well as in the fruits in different development stages (MCNICOL et al., 1985; BRISTOW et al., 1986; ELAD, 2000).

In this context, by applying Tricotec ${ }^{\circledR}$ with a frequency of 15 days in commercial blackberry crops, control of more than $60 \%$ of gray mold was obtained compared with $58 \%$ and $27 \%$ obtained with the fungicides prochloraz and carbendazim, respectively. Furthermore, the highest amount of fruit harvested per week $(5.6 \mathrm{~kg})$ was obtained in this treatment compared to the $4.4 \mathrm{~kg}$ obtained with prochloraz and $3.6 \mathrm{~kg}$ with carbendazim (ZAPATA et al., 2013).

In contrast, for the producer management, the highest diseases incidence was registered, eventually relating to phenomena such as the tolerance of $B$. cinerea to Benomil, Carbendazim or Mancozeb, which has been registered for isolates of $B$. cinerea collected from blackberry crops in Colombia (URIBE et al, 2013) and at high foliage density due to inefficient pruning, which increases the humidity in the plant and creates a favorable microclimate for the pathogens development.

Likewise, the implementation of agronomic labors reduced the incidence of the diseases evaluated. Some of these are the use of an adequate planting distance, a crop support system that allowed plant stems to be separated, as well as the regular pruning that allowed eliminating the non-productive, diseased or damaged branches (stimulating the production of productive sprouts). This last practice facilitates air current passage that eventually affects the humidity conditions required by some of the pathogens.

\section{Establishment of the environmental impact quotient in the field}

One of the measures to reduce the risks related to the use of pesticides in agricultural production is the development and implementation of strategies for integrated pest and diseases management (IPDM). In this sense, the selection and use of low toxicity products, as well as the reduction in the number of active ingredients used and their use frequency and integrating alternatives such as the use of biopesticides and plant extracts, minimizes the negative impacts on the agroecosystem (PRADEL et al., 2009; ORTIZ et al., 2010).

Accordingly, when integrating the use of Tricotec ${ }^{\mathbb{B}}$ Kendal $^{\circledR}$ with two applications of azoxystrobin + difeconazole due to the incidence of anthracnose in this treatment, the lowest EIQf value (5.3) was obtained. Meanwhile, when using Tricotec ${ }^{\circledR}-E \operatorname{coS}$ Swing ${ }^{\circledR}$, two applications of azoxystrobin + difeconazole and three applications of fluopicolide + propineb due to the anthracnose and powdery mildew incidence, showing an EIQf with a value of 21.45. On the contrary, for the producer management, the highest EIQf value was obtained (81.50), so applications of four fungicides (Table $1)$.

The results obtained showed high differences between the strategies proposed compared to the producer management, mainly due to the high EIQ obtained by some of the fungicides used by this study, such as carbendazim (50.5), cymoxanil (35.48) and benomyl (30.24) (Table 1), despite having made four applications of these during the evaluation period.

Although the use of fungicides was integrated into the two strategies proposed, their EIQf was not high due to the low EIQ values of the biopesticide, the biostimulant, and the plant extract used, and although active ingredients such as difenoconazole show an EIQ (41.5) similar to some fungicides used by the producers, its low concentration within the formulation as well as its low use frequency can reduce the risk of adversely affecting the environment, unlike using a fungicide whose active principle was exclusively one of these molecules.

According to the fungicides used by the producer, carbendazim presents the highest EIQ of all the active ingredients, mainly because it is a systemic fungicide that has a half-life of up to five weeks, with a moderate to highly dangerous action in aquatic environments for 
some species of fish, invertebrates, and crustaceans, as well as for some bird species (UNIVERSITY OF HERTFORDSHIRE, 2017a).

In the same way, benomyl also systemic or mancozeb generate risks to human and environmental health; the first has a half-life of up to six weeks and is highly toxic for different fish species (WANG et al., 2009; UNIVERSITY OF HERTFORDSHIRE, 2017b).

Although mancozeb has low toxicity and mobility because it is practically insoluble in water and is strongly adsorbed by soil particles, its main degradation product, ethylenethiourea (ETU), is quite stable and has a high solubility in water. Moreover, it can be a source of surface and groundwater contamination and is considered extremely toxic to amphibians, slightly toxic to fish and mildly toxic to crustaceans (ROEDE et al., 2014). ETU is classified as an animal carcinogen, and a probable human carcinogen (group B2) based on carcinogenicity tests carried out in animals (HURLEY, 1998; LÓPEZFERNÁNDEZ et al., 2017). Also, chronic exposure to this product has been linked to negative effects on the digestive system, the thyroid gland and the nervous system (HAYAMA et al., 2008; LÓPEZ-FERNÁNDEZ et al., 2017).

\section{Effect on the reduction of pesticide residues}

By reducing the number of active ingredients of fungicides used in each of the proposed strategies, the reduction of pesticide residues in the fruit was also observed.

In this sense, with the strategy using Tricotec ${ }^{\circledR}$ Kendal ${ }^{\circledR}$, traces of azoxystrobin $(0.1 \mathrm{mg} / \mathrm{kg})$ and difeconazole $(0.046 \mathrm{mg} / \mathrm{kg})$ were obtained, as this is the only fungicide with two active ingredients used in this treatment; however, these values were below the MRL for pesticides allowed for blackberries (Table 2).

For the Tricotec ${ }^{\circledR}$-EcoSwing ${ }^{\circledR}$ strategy, traces of azoxystrobin $(0.13 \mathrm{mg} / \mathrm{kg})$, difeconazole $(0.078 \mathrm{mg} / \mathrm{kg})$ as well as fluopicolide $(0.22 \mathrm{mg} / \mathrm{kg})$ were obtained, which are products used in this treatment. As in the previous treatment, the traces of residues for the first two products remained within the permitted limits for pesticides in blackberry; however, the traces of the third chemical in this strategy exceeded the permitted MRL of $0.1 \mathrm{mg} / \mathrm{kg}$ (Table 2).

Regarding the producer management, four fungicides, benomyl, carbendazim, one based on propineb + cymoxanil, and mancozeb were used, finding traces of these pesticides in the harvested fruit. Mancozeb, benomyl, carbendazim, and propiconazole constituted the pesticides with the highest amount of residues, exceeding by far the allowed MRL, as well as traces of cymoxanil and cyhalothrin, although relatively low $(0.022 \mathrm{mg} / \mathrm{kg}$ and $0.17 \mathrm{mg} / \mathrm{kg}$, respectively); however, these also exceeded the permitted limits for blackberry (Table 2).

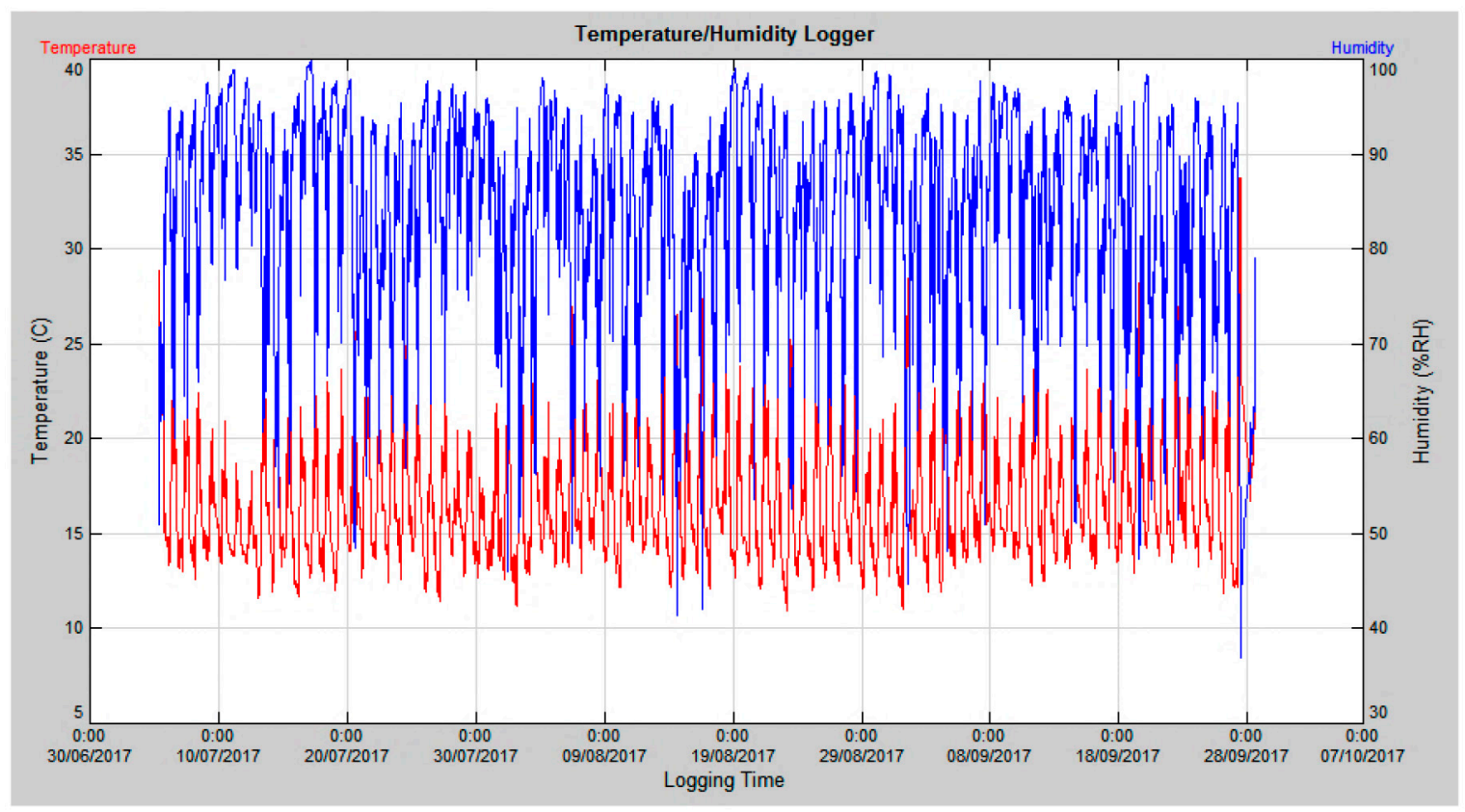

Figure 1. Relative humidity and temperature for the blackberry crop El Carmelo for the period from July 7 to September 28 of 2017. 


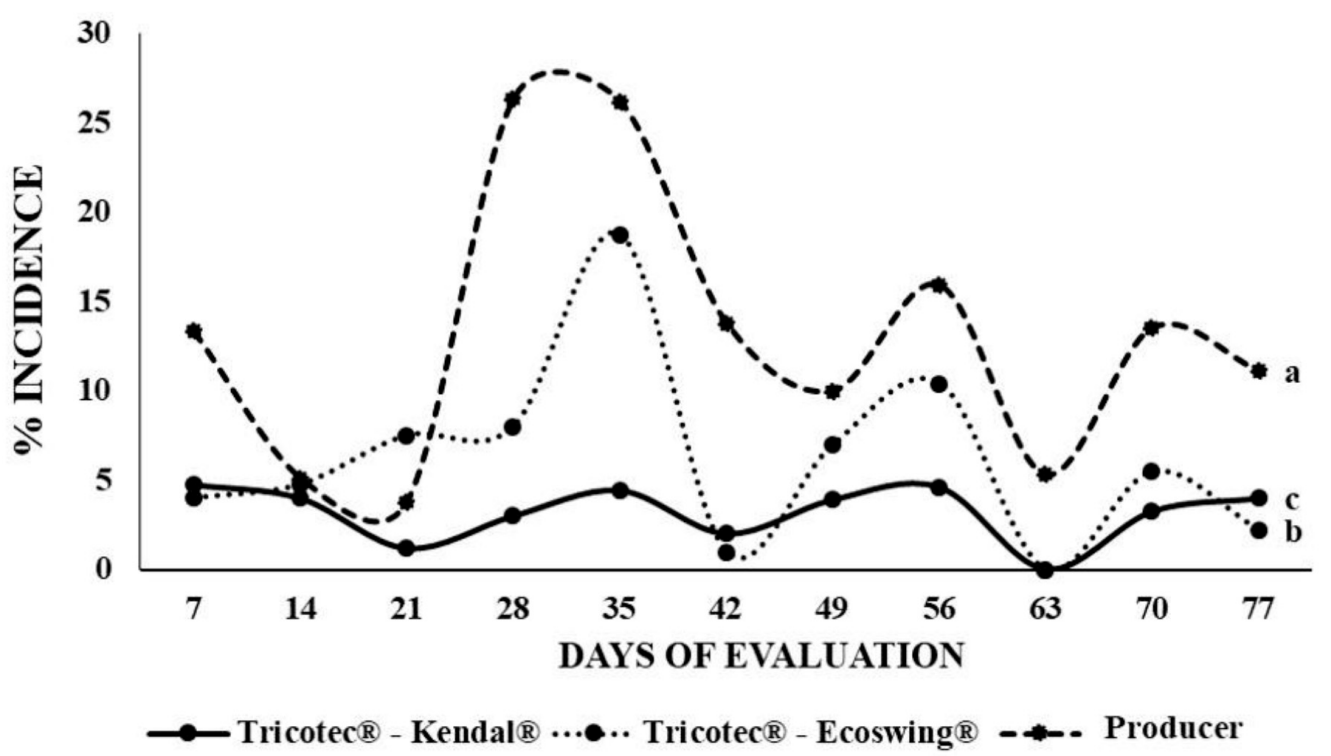

Figure 2. Incidence of gray mold per treatment. The letters show the significant differences between treatments throughout 77 evaluation days according to the nonparametric Kruskal-Wallis test and Dunn's pairwise comparison test with $\alpha$ : 0 .

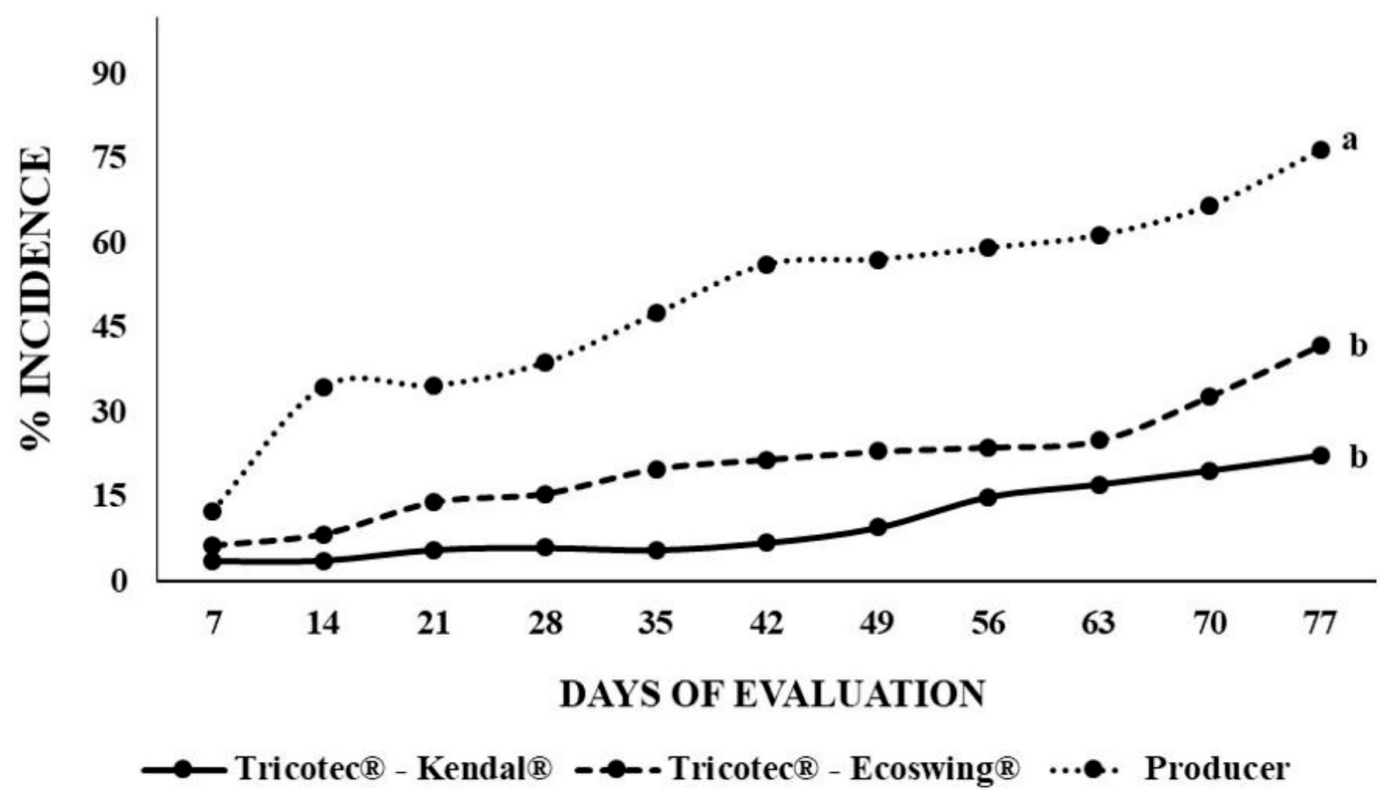

Figure 3. Incidence of anthracnose per treatment. The letters show the significant differences between treatments throughout 77 evaluation days according to the nonparametric Kruskal-Wallis test and Dunn's pairwise comparison test with $\alpha: 0.05$. 


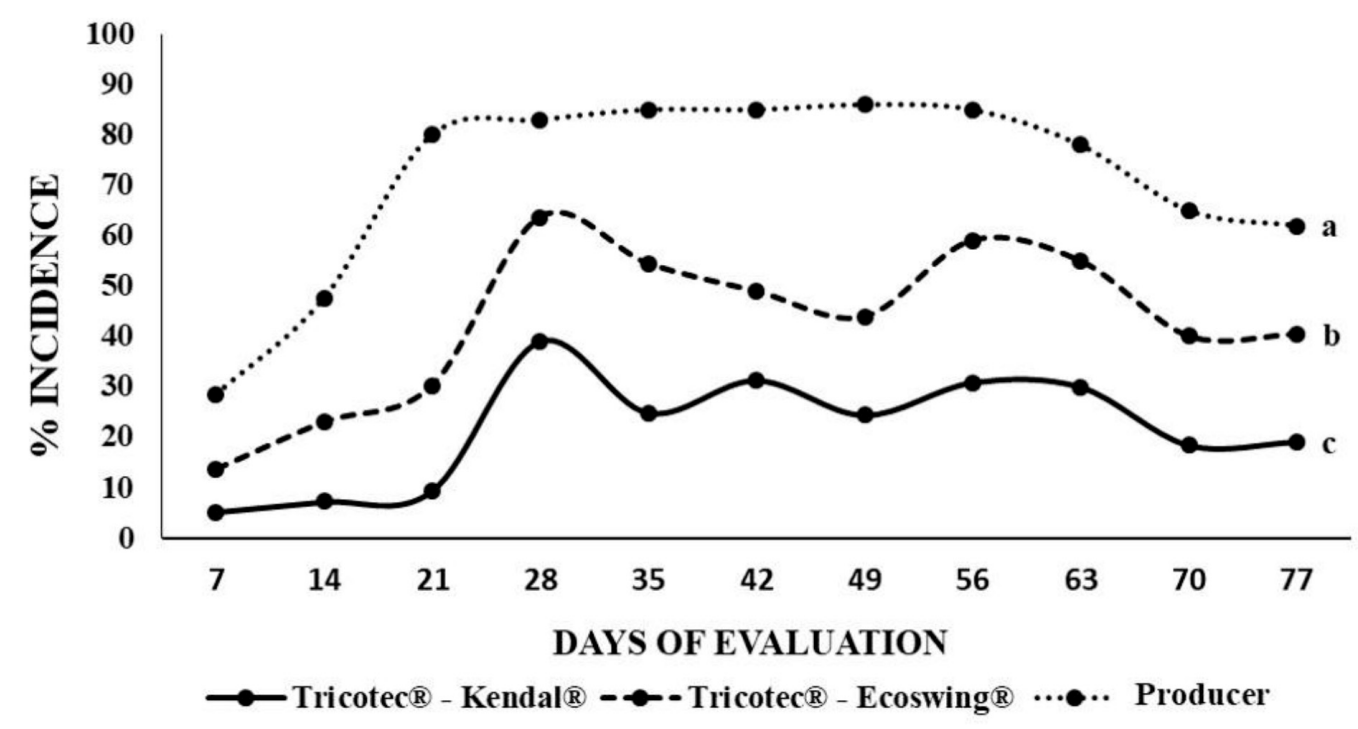

Figure 4. Incidence of powdery mildew per treatment. The letters show the significant differences between treatments throughout 77 evaluation days according to the nonparametric Kruskal-Wallis test and Dunn's pairwise comparison test with $\alpha: 0.05$.

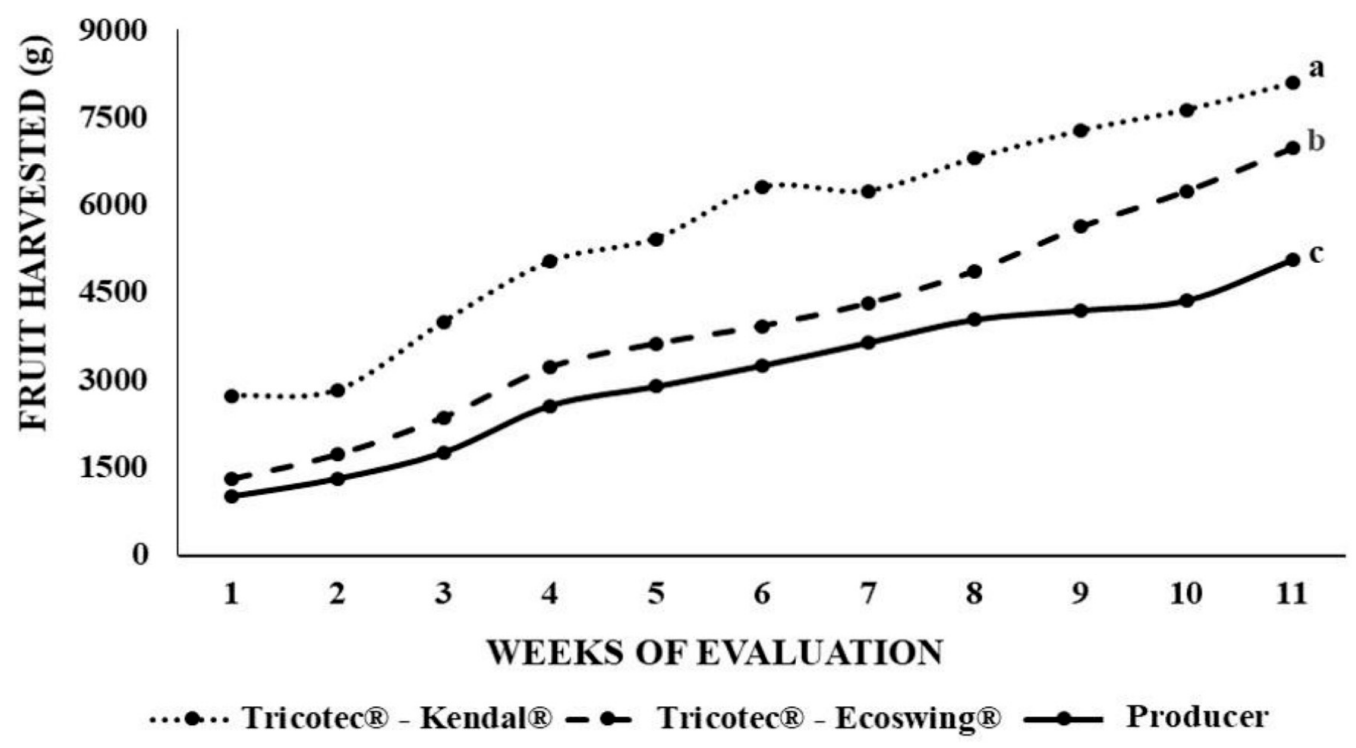

Figure 5. Fruit harvested weekly per treatment. The letters show the significant differences between treatments throughout 77 evaluation days according to the nonparametric Kruskal-Wallis test and Dunn's pairwise comparison test with $\alpha: 0.05$. 
Table 1. Environmental impact quotient in the field (EIQf) per treatment.

\begin{tabular}{|c|c|c|c|c|c|c|c|}
\hline Treatment & $\begin{array}{c}\text { Active ingredient } \\
(* \text { A.I. })\end{array}$ & EIQ & $\%$ A.I. & $\begin{array}{c}\text { Dose } \\
(\mathrm{L}-\mathrm{kg} / \mathrm{ha})\end{array}$ & $\begin{array}{c}\text { No. of } \\
\text { applications }\end{array}$ & $\begin{array}{c}\text { EIQf } \\
\text { (partial) }\end{array}$ & $\begin{array}{l}\text { EIQf } \\
\text { (final) }\end{array}$ \\
\hline \multirow{4}{*}{$\begin{array}{l}\text { Tricotec }^{\circledR}{ }_{-} \\
\text {Kendal }^{\circledR}\end{array}$} & Tricotec & 8 & 0.03 & 0.2 & 7 & 0.34 & \multirow{4}{*}{5.30} \\
\hline & Kendal & 7 & 0.03 & 0.5 & 7 & 0.74 & \\
\hline & Azoxystrobin & 26.92 & 0.2 & 0.2 & 2 & 2.15 & \\
\hline & Difenoconazol & 41.5 & 0.125 & 0.2 & 2 & 2.08 & \\
\hline \multirow{6}{*}{$\begin{array}{l}\text { Tricotec }^{\circledR}{ }_{-} \\
\text {EcoSwing }^{\circledR}\end{array}$} & Tricotec & 8 & 0.03 & 0.2 & 7 & 0.34 & \multirow{6}{*}{21.45} \\
\hline & EcoSwing & 7 & 0.097 & 0.3 & 7 & 1.43 & \\
\hline & Azoxystrobin & 26.92 & 0.2 & 0.2 & 2 & 2.15 & \\
\hline & Difenoconazol & 41.5 & 0.125 & 0.2 & 2 & 2.08 & \\
\hline & Propineb & 16.9 & 0.67 & 0.4 & 3 & 13.59 & \\
\hline & Fluopicolide & 26 & 0.06 & 0.4 & 3 & 1.87 & \\
\hline \multirow{5}{*}{ Producer } & Benomyl & 30.24 & 0.5 & 0.1 & 4 & 6.05 & \multirow{5}{*}{81.50} \\
\hline & Carbendazim & $\mathbf{5 0 . 5 0}$ & 0.5 & 0.2 & 4 & 20.2 & \\
\hline & Propineb & 16.9 & 0.7 & 0.4 & 4 & 18.93 & \\
\hline & Cimoxanil & 35.48 & 0.06 & 0.4 & 4 & 3.41 & \\
\hline & Mancozeb & 25.72 & 0.8 & 0.4 & 4 & 32.92 & \\
\hline
\end{tabular}

Table 2. Pesticide residues obtained in harvested fruit per treatment.

\begin{tabular}{clcc}
\hline Treatment & Molecule found & $\begin{array}{c}\text { Quantity } \\
(\mathrm{mg} / \mathrm{kg})\end{array}$ & $\begin{array}{c}{ }^{*} \text { Tolerance } \\
(\mathrm{mg} / \mathrm{kg})\end{array}$ \\
\hline \multirow{2}{*}{ Tricotec $^{\circledR}$-Kendal ${ }^{\circledR}}$. & Azoxystrobin & 0.1 & 5 \\
& Difeconazole & 0.046 & 0.1 \\
Tricotec & ${ }^{\circledR}$-EcoSwing ${ }^{\circledR}$. & 0.13 & 5 \\
& Azoxystrobin & 0.078 & 0.1 \\
& Difeconazole & 0.22 & 0.01 \\
& Fluopicolide & 2.7 & 0.05 \\
& Mancozeb & 0.24 & $\mathrm{NR}$ \\
& Cypermethrin & 0.17 & 0.01 \\
Producer & Cyhalothrin & 2.1 & 0.1 \\
& Carbendazim & 2.1 & 0.1 \\
& Benomyl & 0.022 & 0.01 \\
& Cymoxanil & 0.18 & 0.01 \\
& Fluopicolide & 0.096 & 0.01 \\
& Propiconazole & 0.25 & $\mathrm{NR}$ \\
\hline
\end{tabular}

NR: No report

* Maximum residue limit (MRL) of pesticides authorized by the European Commission (European Union) for blackberry, code 0154060. Adapted and taken from PLANTS EU Pesticides database 2017:

http://ec.europa.eu/food/plant/pesticides/eupesticidesdatabase/public/?event=pesticide.residue.CurrentMRL\&language=ES 


\section{Conclusions}

From the proposed strategies, by integrating the use of suitable agronomic labors such as an adequate planting distance, an efficient plant support system and regular prunings with the applications of Tricotec $®$ and Kendal ${ }^{\circledR}$, together with the fungicide based on azoxystrobin and difeconazole, the highest efficiency in the control of the three diseases assessed, i.e., gray mold, anthracnose, and powdery mildew, were obtained. Moreover, the lowest incidence values, as well as the highest amount of average fruit harvested, were also achieved with this strategy. This allowed decreasing the number of active ingredients in the fungicides used as well as the number of applications, which led to obtaining the lowest environmental impact quotient and a lower residuality of pesticides in the fruit harvested.

\section{Acknowledgments}

The authors wish to thank Corporación Colombina de Investigación Agropecuaria - AGROSAVIA and Universidad Nacional de Colombia for generating the preliminary information used in this work within the framework of the project "Research, development and technology transfer in blackberry fruit production syste$\mathrm{ms}$ in conventional producer regions of the department of Cundinamarca" financed by Convenio del Corredor Tecnológico Agroindustrial Derivado 2, starting point of this research and further publication. Moreover, many thanks to the blackberry producers that participated in this research for their invaluable support that allowed the development of this study.

\section{References}

AMSALEM, L.; FREEMAN, S.; RAV-DAVID, D.; NITZANI, Y.; SZTEJNBERG, A.; PERTOT, I.; ELAD, Y. Effect of climatic factors on powdery mildew caused by Sphaerotheca macularis f. sp. fragariae on strawberry. European Journal of Plant Pathology, Berlin, v. 114, n. 3, p. 283-292, 2006.

ARENAS, A.; ÁLVAREZ, E.; AFANADOR-KAFURI, L.; MEJÍA J.F.; GONZÁLEZ, A. Especies de Colletotrichum asociadas con la antracnosis de la mora de Castilla (Rubus glaucus, Benth.) en el Valle del Cauca. Fitopatología Colombiana, Palmira, v.31, n. 1, p.7-14, 2007.

BOYZO, J.; ROJAS, H.; REBOLLAR A. Biorational treatments to manage dry berry of blackberry caused by Peronospora sparsa. Crop Protection, Amsterdam, v.76, p.121-126, 2015.
BRISTOW, P.R.; MCNICOL, R.J.; WILLIAMSON, B. Infection of strawberry flowers by Botrytis cinerea and its relevance to grey mould development. Annals of Applied Biology, Warwickshire, v.109, n.3, p. 545-554, 1986.

BRITTAIN C.A.; VIGHI M.; BOMMARCO R.; SETTELE J.; POTTS S.G. Impacts of a pesticide on pollinator species richness at different spatial scales. Basic and Applied Ecology, Amsterdam, v.11, n. 2, p.106-115, 2010.

CARISSE, O.; MORISSETTE-THOMAS, V.; VAN DER HEYDEN, H. Lagged association between powdery mildew leaf severity, airborne inoculum, weather, and crop losses in strawberry. Phytopathology, St. Paul, v.103, n. 8, p. 811-821, 2013.

CORNELL UNIVERSITY. New York State Integrated Pest Management of Cornell University. List of pesticide active ingredient EIQ values. 2017. Disponível em: https://nysipm.cornell.edu/eiq/list-pesticide-activeingredient-eiq-values/. Acesso em: 15 jul. 2017.

ELAD, Y. Biological control of foliar pathogens by means of Trichoderma harzianum and potential modes of action. Crop Protection, Amsterdam, v.19, n. 8, p. 709-714, 2000.

ELAD, Y. Mechanisms involved in biological control of Botrytis cinerea incited diseases. European Journal of Plant Pathology, Berlin, v. 102, n. 8, p. 719-732, 1996.

EUROPEAN UNION. European Commission. EU Pesticides database. 2017. Disponível em: http://ec.europa.eu/food/plant/pesticides/ eupesticidesdatabase/public/?event=pesticide.residue. CurrentMRL\&language=ES. Acesso em: 20 out. 2017.

GARCIA-BRUGGER, A.; LAMOTTE, O.; VANDELLE, E.; BOURQUE, S.; LECOURIEUX, D.; POINSSOT, B.; WENDEHENNE, D.; PUGIN A. Early signaling events induced by elicitors of plant defenses. Molecular Plant Microbe Interactions, St. Paul, v. 19, n.7, p.11- 724, 2006.

GUEVARA, E.; HERNÁNDEZ, E.; ARISPURO, I.; TÉLLEZ, M. Oligosacarinas derivadas de pared celular: actividad biológica y participación en la respuesta de defensa de plantas. Revista Mexicana de Fitopatología, Texcoco, v. 28, n. 2, p.144-155, 2010. 
HAYAMA, T.; TAKADA, M. Simple and rapid method for the determination of ethylenebis dithiocarbamate fungicides in fruits and vegetables using liquid chromatography with tandem mass spectrometry. Analytical and Bioanalytical Chemistry. Berlin, v. 392, n. 5, p.969-976, 2008.

HURLEY, P.M. Mode of carcinogenic action of pesticides inducing thyroid follicular cell tumors in rodents. Environmental Health Perspectives, Durham, v. 106, n. 8 , p. 437-45. 1998.

ICA - Instituto Colombiano Agropecuario. National Registries November 01 de 2017. Disponível em: https://www.ica.gov.co/getdoc/d3612ebf-a5a6-47028d4b-8427c1cdaeb1/REGISTROS-NACIONALESPQUA-15-04-09.aspx. Acesso em: 12 jun. 2017.

IDEAM - Instituto de Hidrología, Meteorología Y Estudios Ambientales de Colombia. Atlas climatológico de Colombia, interactivo año 2015. Bogotá, 2015. Disponível em: http://atlas.ideam.gov.co/visorAtlasClimatologico. html. Acesso em: 10 jun. 2016.

JARVIS, W. R. The infection of strawberry and raspberry fruits by Botrytis cinerea Fr. Annals of Applied Biology, Warwickshire, v.50, n.3, p.569-575, 1962.

KOVACH, J.; PETZOLDT, C.; DEGNI, J.; TETTE, J. A method to measure the environmental impact of pesticides. New York's Food and Life Sciences Bulletin, New York, v.139, p.1-8, 1992.

LÓPEZ-FERNÁNDEZ, O.; POSE-JUAN, E.; RIALOTERO, R.; SIMAL-GÁNDARA, J. Effects of hydrochemistry variables on the half-life of Mancozeb and on the hazard index associated to the sum of Mancozeb and ethylenethiourea. Environmental Research, Amsterdam, v. 154, p.253-260, 2017.

MARULANDA, M.; ISAZA, V.; RAMÍREZ, A. Identificación de la especie Colletotrichum responsable de la antracnosis en la mora de castilla en la región cafetera. Scientia et Technica, Pereira, v.13, n. 37, p.122-170, 2007.

McNICOL, R. J.; WILliAMSON, B.; DOLAN, A. Infection of red raspberry styles and carpels by Botrytis cinerea and its possible role in post-harvest grey mould. Annals of Applied Biology, Warwickshire, v. 106, n. 1, p. 49-53, 1985.

MERT-TÜRK, F. Phytoalexins: Defense or just response to stress? Journal of Cell and Molecular Biology, Turkey, v.1, n. 1, p.1-6, 2002.
MOLINA, S.; DE LA ROTTA, M.; TORRES, E. Incidencia de infecciones quiescentes de Botrytis cinerea en flores y frutos de mora de castilla (Rubus glaucus, Benth.). Agronomía Colombiana, Bogotá, v. 22, n.2, p.101-109, 2004.

NARANJO-MARÍN, J. M. Propuesta de un perfil de riesgo químico establecido para la mora de Castilla (Rubus glaucus Benth) producida en Colombia. 2011. Máster (Gerencia de Programas Sanitarios en Inocuidad de Alimentos) - Universidad para la Cooperación Internacional, San José, 2011.

ORTIZ, O.; PRADEL, W. Some useful references related to impact evaluation. In: ORTIZ, O. (ed.). Introductory guide for impact evaluation in integrated pest management (IPM) programs. Lima: International Potato Center, 2010. p.14-74.

PRADEL, W.; FORBES, G.; ORTIZ, O.; COLE, D.; WANIGARATNE, S.; MALDONADO, L. Use of the environmental impact quotient to estimate impacts of pesticide usage in three Peruvian potato production areas. Lima: International Potato Center, 2009. p.18. (Working paper)

REBOLLAR-ALVITER, A.; SILVA-ROJAS, H.V.; LÓPEZ-CRUZ, I.; BOYZO-MARÍN, J.; ELLIS, M.A. Fungicide spray programs to manage downy mildew (dryberry) of blackberry caused by Peronospora sparsa. Crop Protection, Amsterdam, v.42, p.49-55, 2012.

ROEDE, J.R.; MILLER, G.W. Mancozeb. In: WEXLER, P. (ed.). Encyclopedia of toxicology. Bethesda: Academic Press, 2014. p. 5220.

SIEMBRA. Gráficas de contexto agropecuario del cultivo de la mora. 2018. Disponível em: http://www. siembra.gov.co/Regional/ContextoAgro/Reporte. Acesso em: 01 fev. 2018.

SORA, Á; FISCHER, G; FLÓREZ, R. Almacenamiento refrigerado de frutos de mora de Castilla (Rubus glaucus Benth.) en empaques con atmósfera modificada. Agronomía Colombiana, Bogotá, v. 24, n. 2, p.306-316, 2006.

TAMAYO, P. Principales enfermedades del tomate de árbol, la mora y el lulo en Colombia. Rionegro: Impresos Begón, 2001. p.44. (Boletín técnico, 20)

UNIVERSITY OF HERTFORDSHIRE. PPDB: pesticide properties database: benomyl. 2017b. Disponível em: http://sitem.herts.ac.uk/aeru/iupac/Reports/66.htm. Acesso em: 10 fev. 2017. 
UNIVERSITY OF HERTFORDSHIRE. PPDB: Pesticide properties patabase: carbendazim. 2017a. Disponível em: http://sitem.herts.ac.uk/aeru/footprint/es/ Reports/116.htm. Acesso em: 10 fev. 2017.

URIBE, L; ZAPATA, J; COTES, A.M. Sensibilidad de Botrytis cinerea a siete fungicidas comúnmente empleados para su control en cultivos de mora. In: ZAPATA, J. (Ed.). Desarrollo de prototipos de bioplaguicida a base de Rhodotorula glutinis LvCo7 para el control de Botrytis cinerea en cultivos de mora. Bogotá: Produmedios, 2013. p.11-25.

VANENGELSDORP, D.; MEIXNER, M. A historical review of managed honey bee populations in Europe and the United States and the factors that may affect them. Journal of Invertebrate Pathology, Amsterdam, v. 103, Suppl. 1, p.S80-S95, 2010.

WANG X.; SONG, M.; GAO, C.; DONG, B.; ZHANG, Q.; FANG, H.; YU, Y. Carbendazim induces a temporary change in soil bacterial community structure. Journal of Environmental Sciences, Amsterdam, v.21, n.12, p.16791683, 2009.
WEIR, B.; JOHNSTON, P.; DAMM, U. The Colletotrichum gloeosporioides species complex. Studies in Mycology, Amsterdam, v.73, n. 1, p.115-180, 2012.

WIGHTWICK, A.; WALTERS, R.; GRAEME, A.; REICHMAN, S.; MENZIES, N. Environmental risks of fungicides used in horticultural production systems. London: InTech, 2010. p.273-304. Disponível em: http:// www.intechopen.com/embed/fungicides/environmentalrisks-of-fungicides-used-in-horticultural-productionsystems. Acesso em: 12 set. 2016.

ZAPATA, J; COTES, A.M. Eficacia de dos prototipos de bioplaguicida a base de Rhodotorula glutinis cepa LvCo7 y un bioplaguicida a base de Trichoderma koningiopsis cepa Th003 en el control de $B$. cinerea en cultivos de mora. In: ZAPATA, J. (Ed.). Desarrollo de prototipos de bioplaguicida a base de Rhodotorula glutinis LvCo7 para el control de Botrytis cinerea en cultivos de mora. Bogotá: Produmedios, 2013. p.73-79. 